\title{
Using internally transcribed spacer 2 sequences to re-examine the taxonomic status of several cryptic species of Trichogramma (Hymenoptera: Trichogrammatidae)
}

\author{
ZHeNG-XI LI ${ }^{1}$, Li ZHENG ${ }^{2}$ and Zuo-RuI $\mathrm{SHEN}^{1 *}$ \\ ${ }^{1}$ Department of Entomology, China Agricultural University, 2 Yuanmingyuan XiLu, Beijing 100094, P.R. China; \\ e-mail: zxli@cau.edu.cn \\ ${ }^{2}$ Present address: Institute of Dryland Crop Research, HeBei Academy of Agricultural and Forestry Sciences, Hengshui 053000, \\ P.R. China
}

Key words. Internally transcribed spacer 2, ITS2, cryptic species, molecular taxonomy, Trichogramma chilonis, T. confusum, T. brassicae, T. maidis, T. evanescens

\begin{abstract}
Mass releases of Trichogramma confusum Viggiani and T. maidis Pintureau \& Voegele are widely used to control lepidopterous pests. They have long been considered to be the subspecies of T. chilonis Ishii and T. brassicae Bezdenko, respectively. To re-examine the taxonomic status of these closely related Trichogramma species, the internally transcribed spacer 2 (ITS2) of ribosomal DNA was used as a molecular marker to detect between-species differences. The ITS2 regions of 7 different Trichogramma species collected from China, Germany and France were sequenced and the inter-species distances were calculated. To quantify within-species sequence variation, the ITS2 regions of 6 geographical populations of $T$. dendrolimi Matsumura collected from across China were sequenced and compared. The results show that the ITS2 sequences of T. confusum and T. maidis are sufficiently different from those of T. chilonis and T. brassicae, respectively, that it is difficult to group them as cryptic species, whereas there are only minor differences between the T. dendrolimi populations. The ITS2 sequences identified in this study, coupled with 67 ITS2 sequences from a wide geographical distribution retrieved from GenBank, were then used for phylogenetic analyses. The results support previous records of minor within-species ITS2 sequence divergence and distinct interspecies differences. The cladograms show the $T$. maidis sequence clustered within $T$. evanescens Westwood, while the ITS2 sequences of $T$. confusum and $T$. chilonis are clustered in different branches. Taken together, these data suggest that T. maidis is not $T$. brassicae, but a cryptic or sibling species of $T$. evanescens; $T$. confusum and $T$. chilonis are not cryptic species but two closely related sister species.
\end{abstract}

\section{INTRODUCTION}

Identification and classification of Trichogramma species are difficult because of their small size. The closely related Trichogramma species or cryptic species complexes are extremely difficult or impossible to distinguish morphologically. For example, $T$. confusum and $T$. maidis have long been considered to be subspecies of $T$. chilonis and $T$. brassicae, respectively (Lin, 1994). Based on the examination of more than 10 thousand specimens on slides, mostly collected by sweeping from all over China, Lin (1994) described 39 genera and 128 species of the total of 142 species in 41 genera in China.

Trichogramma Westwood is the type genus of the Trichogrammatidae family, most species of which parasitize the eggs of lepidopterous pests. The larvae are morphologically indistinguishable, and the adults very difficult to differentiate. The identity of these egg parasitoids was based almost exclusively on the morphology of the male genitalia (Nagarkatti \& Nagaraja, 1971; Nagarkatti \& Nagaraja, 1977; Sorokina, 1993), but male wasps occur in very low proportions or are absent in natural populations (Aeschlimann, 1990). While the taxonomy of the genus Trichogramma is still being studied (Pinto, 1992; Pinto \& Stouthamer, 1994; Neto \& Pintureau, 1995), mass releases of these egg parasitoids for the biological control of crop pests have gained increasing attention worldwide. Trichogramma species are used to control over 20 pest species on corn, cotton, rice, sugarcane, vegetables and fruit trees. We used not only the native species, T. dendrolimi, T. ostriniae, T. evanscens and T. confusum, but also commercially available Trichogramma such as $T$. brassicae supplied by Biocare (Einbeck, Germany) and $T$. maidis produced by BASF (Valbonne, France) to control the European corn borer, Ostrinia nubilalis Hübner (Lepidoptera: Pyralidae) in the corn fields of HengShui in HeBei province, China. In Germany and France, T. brassicae is considered to be a strain of $T$. maidis (Hassan \& Zhang, 2001).

With the extensive application of Trichogramma for biocontrol worldwide in the middle of $20^{\text {th }}$ century, the identification of species and strains of Trichogramma became important (Smith \& Hubbes, 1986). Quednau (1960) pointed out that only individuals reared in the same host at the same temperature could be differentiated. Lack of type specimens is a key factor affecting the accurate classification of Trichogramma species (Pang, 1999). For example, there is only one incomplete female specimen of T. evanescens. Pintureau \& Voegele (1980) re-described $T$. evanescens when they described $T$. maidis

\footnotetext{
* To whom correspondence should be addressed: Tel: +86 (0)10 62893015; Fax: +86 (0)10 62817605; e-mail: ipmist@cau.edu.cn
} 
and found that the previously described $T$. evanescens were actually $T$. maidis. Pintureau (1987) classified $T$. maidis as T. brassicae and Lin (1994) accepted this nomenclature. T. chilonis was first described by Ishii (1941) but there is no holotypes for verification. Nagarkatti \& Nagaraja (1979) chose a male specimen mounted on a glass slide from the syntypes of $T$. chilonis described by Ishii (1941) as its lectotype. Meanwhile they classified $T$. chilonis as $T$. confusum (Viggiani, 1976). Lin (1994) agreed with this classification. However, T. confusum is common in China and it is essential to reconsider its taxonomic status according to Pang (1999). Viggiani's description of $T$. confusum was very simple and there are no holotypes for comparison, but there is a detailed figure of the male genitalia for reference. It seems incorrect to classify $T$. confusum as T. chilonis on the basis of this figure (Pang, 1999).

Many methods were used to discriminate sibling species of Trichogramma in addition to morphological comparisons (Pinto et al., 1997), such as allozyme analyses (Pinto et al., 1992, 1993; Pintureau, 1993) and reproductive compatibility tests (Pinto et al., 1991; Stouthamer et al., 1996, 2000a, b). Recently closely related or cryptic species were characterized using DNA-based methods (Landry et al., 1993; Vanlerberghe-Masutti, 1994; Sappal et al., 1995; Landais et al., 2000). Ribosomal DNA (rDNA) consists of several regions (genes and spacers) that evolve at different rates, among which the internal non-coding transcribed spacer (ITS) region usually evolves faster than the coding regions (Hoy, 1994). Many of the phylogenetic relationships between Trichogramma species deduced from ITS2 sequences were recorded by previous studies (Orrego \& Silva, 1993; van Kan et al., 1996, 1997; Pinto et al., 1997; Schilthuizen \& Stouthamer, 1997; Stouthamer et al., 1999; Chang et al., 2001; Pinto et al., 2002), which showed that the DNA sequence of the internally transcribed spacer (ITS2) of Trichogramma wasps could be used for species identification. Consistent differences occur among species, whereas the spacer sequences show little variation within species. As ITS2 sequences can be used to identify cryptic species, we used them to distinguish the proposed cryptic species of Trichogramma.

\section{MATERIAL AND METHODS}

\section{Insects}

We established 12 iso-female lines, six from different Trichogramma species and six from geographical populations of another species (Table 1). T. brassicae, T. maidis and $T$. embryophagum (Hartig) were identified and provided by Sherif A. Hassen of the Federal Biological Research Center for Agriculture and Forestry, Institute for Biological Control, Heinrichstr, Darmstadt, Germany. T. brassicae was purchased from Biocare (Einbeck, Germany) and T. maidis from BASF (Valbonne, France). Six geographical populations of $T$. dendrolimi were collected from noctuid eggs on corn, cotton, rice or fruit trees in China. We selected $T$. dendrolimi for a within-species between-population study because the largest number of collections are available for this species, and it has the largest geographical distribution in China. The lines of T. brassicae, $T$. maidis and T. embryophagum were maintained in the Department of Entomology, China Agricultural University in Beijing. Other lines were maintained at the Biological Control Centre, Beijing Academy of Agriculture and Forestry Sciences, Beijing, China, by rearing $T$. chilonis, $T$. confusum and $T$. dendrolimi in the eggs of tussore worm, Antheraea pernyi Guérin-Méneville and the other lines in the eggs of the rice moth, Corcyra cephalonica (Stainton), at $20-25^{\circ} \mathrm{C}, \mathrm{RH} 75-80 \%$ and $16 \mathrm{~L}$ : 8D. Individual rearing was used to avoid linebreeding. Individual neonate wasps from different cultures were placed in sterile 1.5 $\mathrm{ml}$ tubes at $-80^{\circ} \mathrm{C}$ for further analysis. Meanwhile, 10 freshly emerged wasps from each line were soaked in acetic acid prior to morphological identification. Trichogramma specimens were identified using the procedure of Lin (1994).

\section{DNA isolation}

DNA was extracted with Chelex-100 (Bio-Rad, California, USA) (Orrego \& Silva, 1993) as follows: one previously frozen wasp was macerated in $50 \mu 1$ Chelex-100 (5\%) and $4 \mu 1$ proteinase $\mathrm{K}(20 \mathrm{mg} / \mathrm{ml})$ (Merck, Darmstadt, Germany) with a tissue grinder. The mixture was incubated at $56^{\circ} \mathrm{C}$ for $4 \mathrm{~h}$, followed by $10 \mathrm{~min}$ at $95^{\circ} \mathrm{C}$. The extracted genomic DNA was then used for PCR amplification.

TABLE 1. Strains, species, site and time of collection of the Trichogramma used in this study.

\begin{tabular}{lll}
\hline Strains* & Species & Collection site / time \\
\hline con_JL & T. confusum & Changchun, Jilin, China, 1999 \\
mai_FRA & T. maidis & BASF, Valbonne, France, 2000 \\
bra_GER & T. brassicae & Biocare, Einbeck, Germany, 2000 \\
eva_YQ & T. evanescens & Yanqing, Beijing, China, 1999 \\
ost_JL & T. ostriniae & Changchun, Jilin, China, 1999 \\
emb_GER & T. embryophagum & Biocare, Einbeck, Germany, 2000 \\
den_CHA & T. dendrolimi & Chang'an, Shanxi, China, 1994 \\
den_JL & T. dendrolimi & Changchun, Jilin, China, 1993 \\
den_GZ & T. dendrolimi & Guangzhou, Guangdong, China, 1996 \\
den_RH & T. dendrolimi & Renhe, Jilin, China, 1994 \\
den_XZ & T. dendrolimi & Xuzhou, Jiangsu, China, 1994 \\
den_YBL & $T$. dendrolimi & Yabuli, Heilongjiang, China, 1994 \\
\hline
\end{tabular}

\footnotetext{
* The first 3 letters of species names suffixed with the corresponding strain names represent acronyms for strain designation.
} 


\section{PCR amplification of ITS2, cloning and sequencing}

PCR was performed in $50 \mu 1$ reaction volumes using a Hybaid thermocycler (Fisher Scientific Pte Ltd., Singapore) with $5 \mu 1$ (10×) PCR buffer, $0.8 \mu 1 \mathrm{dNTP}$ mixture (each in a $10 \mathrm{mM}$ concentration), $0.5 \mu \mathrm{l}$ forward and reverse primers (each in 0.25 $\mu \mathrm{M}), 2 \mu \mathrm{l}$ genomic DNA, $0.2 \mu 1$ Taq DNA polymerase (GibcoBRL, Eggenstein, Germany, $5 \mathrm{U} / \mu 1$ ), and $41 \mu \mathrm{l}$ sterile water. The ITS2 region was amplified using the following primers: forward, 5'-TTCTCGCATCGATGAAGAACG-3' (ITSN2) located in the 5.8S rDNA; reverse, 5'-TCCTCCGCTTATTGATA TGC-3' (ITSB) located in the 28S rDNA (Amornsak et al., 1998). The PCR cycling program was $3 \mathrm{~min}$ at $95^{\circ} \mathrm{C}$ followed by 35 cycles of $1 \mathrm{~min}$ at $94^{\circ} \mathrm{C}, 1 \mathrm{~min}$ at $53^{\circ} \mathrm{C}$, and $1 \mathrm{~min}$ at $72^{\circ} \mathrm{C}$ with $7 \mathrm{~min}$ at $72^{\circ} \mathrm{C}$ after the last cycle. PCR products were subjected to electrophoresis on a $1.5 \%(\mathrm{w} / \mathrm{v})$ agarose gel. Gels were stained with ethidium bromide. Molecular weight standards (100 bp DNA ladder) were run along with the samples for reference. The target bands (approximately 600 650 bp) were then excised from the agarose gel and recovered using a QIAquick DNA Purification kit (Qiagen, Hilden, Germany), and $4 \mu \mathrm{l}$ of the final eluted solution $(30 \mu \mathrm{l})$ were ligated into pGEM-T Vector System I (Promega, Madison, USA) following the protocol provided by the manufacturer. The ligated products were then transformed into E. coli DH5 $\alpha$ competent cells (Life Technologies, Rockville, USA). The colonies containing an insert of correct size were checked by PCR using the same primers as described above. One to 3 positive clones from each line were selected and sent for sequencing (Sangon, Shanghai, China). To check the accuracy of the automatic sequencer, some clones were sequenced in two directions. Clones from different individuals of the same line were sequenced for a comparative analysis of the between individual (within line) sequence variation.

\section{Alignment and sequence divergence analyses}

The ITS2 regions sequenced in this study and additional 67 ITS2 sequences obtained from GenBank, representing a wide variety of Trichogramma species, were aligned in ClustalW (1.82) (Higgins et al., 1994). The sequences from GenBank are all previously published, except the sequence for $T$. confusum con_GZ (GenBank accession no. AY244461) (Table 2). This unpublished ITS2 sequence comes from an important geographical population of $T$. confusum in southern China. A fast pairwise alignment algorithm was chosen for global multiple alignment of ITS2 sequences. The alignment is progressive and considers the sequence redundancy. DNA Identity Matrix (Unitary Matrix) was selected to generate the alignment, which creates a positive score for a match, and a score of -10000 for a mismatch. The penalty for opening a gap is 10 ; the penalty for extending a gap is 0.05 , and the gap separation penalty is 8 . The end-unaligned sequences of the multiple alignments were carefully trimmed.

Sequence divergence analyses at the levels of interspecies and intraspecies were conducted using MEGA version 2.1 (Kumar et al., 2001). For ITS2 sequence divergence analysis, a total of 27 groups were set up from 79 Trichogramma taxa (12 identified in this study and 67 retrieved from GenBank), i.e. 6 strains of $T$. dendrolimi, 11 of $T$. deion, 6 of T. pretiosum), 5 of T. platneri, 4 of $T$. bourarachae, 4 of $T$. evanescens, 4 of $T$. cordubensis, 3 of T. alpha, 3 of T. turkestanica, 3 of T. kaykai, 3 of T. californicum, 3 of T. minutum, 2 of T. pratti, 2 of T. itsybitsi, 2 of $T$. brassicae, 2 of T. aurosum, 2 of $T$. sathon, 2 of T. sibericum, 2 of $T$. confusum, 2 of $T$. exiguum, 2 of $T$. cacoeciae, 1 of $T$. maidis, 1 of $T$. chilonis, 1 of T. ostriniae, 1 of T. embryophagum, 1 of $T$. oleae, 1 of $T$. nubilale. The ITS2 sequence of Nasonia vitripennis (GenBank accession no. U02960) (Camp- bell et al., 1993), a species of Pteromalidae in the same superfamily Chalcidoidea as Trichogrammatidae, and the ITS2 of Uscana semifumipennis (GenBank accession no. U74608) (Doutt \& Viggiani, 1968), a member of a related genus, were incorporated into the 79 Trichogramma ITS2 sequences for net between groups distance analysis. We chose 7 groups from the 27 groups for within group analyses, because each of them contained at least 4 members (strains), the largest numbers available. Net Between Groups and Within Groups methods in MEGA were used to compute average distances. The net average distance between two groups is given by:

$$
d_{A}=d_{X Y}-\frac{\left(d_{X}-d_{Y}\right)}{2}
$$

where $d_{X Y}$ is the average distance between groups $\mathrm{X}$ and $\mathrm{Y}$, and $d_{X}$ and $d_{Y}$ are the mean within-group distances. For each group, an arithmetic average is computed for all valid pairwise comparison. Distance algorithm Kimura 2-parameter (Kimura, 1980) in MEGA was used to compute genetic distances. The complete-deletion option and pairwise-deletion option were alternatively used. For the first option, sites containing missing data or alignment gaps are removed before the analysis begins; for the latter, sites containing missing data or alignment gaps are removed as the need arises during the analysis. Both transitions and transversions were included in the analyses, assuming that the substitution rates do not vary among sites.

\section{Phylogenetic analyses}

Phylogenetic analyses were based on the sequence alignments constructed by ClustalW with options and parameters as described above. Because different tree-building algorithms make different evolutionary assumptions, aligned sequences were evaluated by parsimony, maximum-likelihood and neighbour-joining methods. For parsimony, the branch-andbound method of DNA parsimony algorithm, version $3.572 \mathrm{c}$ of PHYLIP (Felsenstein, 1993) was used. Bootstrapping was performed with the heuristic search option for 1000 replications. To construct maximum-likelihood trees, the fastDNAml program of PHYLIP (Olsen et al., 1994), based in part on Joseph Felsenstein's nucleic acid sequence Maximum Likelihood method (Felsenstein, 1993), was used with a transition / transversion ratio of 2.0. The neighbour-joining method (Saitou \& Nei, 1987) of MEGA was used to construct a distance tree. The number of nucleotide substitutions per site was estimated by distance model Kimura 2-parameter (Kimura, 1980). Gaps or missing data were treated using Complete Deletion option in MEGA, which removed the sites that contain missing data or alignment gaps before the analysis begins. Both transitions and transversions were considered in the substitution analyses, assuming the substitution rates do not vary among sites. Distance method Kimura 2-parameter (Pairwise distances) was used, and bootstrapping of 1000 replications was performed to test the reliability of the putative tree. A total of 79 Trichogramma ITS2 sequences (12 identified in this study and 67 retrieved from GenBank) were used in the analyses, using U. semifumipennis as the outgroup based on previous phylogenetic work (Schilthuizen \& Stouthamer, 1997).

\section{RESULTS}

\section{ITS2 sequences and alignment}

The 18 ITS2 sequences identified in this study were registered in GenBank with the accession numbers listed in Table 3. The registered sequences are complete ITS2 sequences containing no flanking sequences of $5.8 \mathrm{~S}$ and 28S. The ITS2 sequences showed little difference in length between different individuals of the same line and 
TABLE 2. Reference ITS2 sequences retrieved from GenBank for phylogenetic analysis.

\begin{tabular}{|c|c|c|c|c|c|c|c|c|c|}
\hline \multirow{2}{*}{$\frac{\text { Strains }^{\mathrm{a}}}{\text { dei_DLC1 }}$} & \multirow{2}{*}{$\frac{\text { Species }}{\text { T. deion }}$} & \multirow{2}{*}{$\frac{\mathrm{GB} \mathrm{ID}^{\mathrm{b}}}{\mathrm{U} 76224}$} & \multicolumn{2}{|c|}{ Size $(b p)^{c}$ References } & \multirow{2}{*}{$\frac{\text { Strains }^{\mathrm{a}}}{\text { dei_DPTL }}$} & \multirow{2}{*}{$\frac{\text { Species }}{\text { T. deion }}$} & \multirow{2}{*}{$\frac{\mathrm{GB} \mathrm{ID}^{\mathrm{b}}}{\mathrm{AF} 082826}$} & \multirow{2}{*}{$\begin{array}{l}\text { Size }(b p)^{c} \\
408\end{array}$} & \multirow{2}{*}{$\begin{array}{l}\text { References } \\
\text { Stouthamer et al., } \\
1999\end{array}$} \\
\hline & & & 406 & Pinto et al., 1997 & & & & & \\
\hline \multicolumn{2}{|c|}{ kay_KLC187T. kaykai } & U76229 & 469 & Pinto et al., 1997 & dei_DRIV & T. deion & AF082827 & 407 & $\begin{array}{l}\text { Stouthamer et al., } \\
1999\end{array}$ \\
\hline kay_KSH1 & T. kaykai & U76228 & 462 & Pinto et al., 1997 & dei_DRV1 & T. deion & AF082824 & 404 & $\begin{array}{l}\text { Stouthamer et al., } \\
1999\end{array}$ \\
\hline pre_PIRV & T. pretiosum & U76227 & 413 & Pinto et al., 1997 & dei_DSHE & T. deion & AF082825 & 404 & $\begin{array}{l}\text { Stouthamer et al., } \\
1999\end{array}$ \\
\hline pre_PRV4 & T. pretiosum & U76226 & 409 & Pinto et al., 1997 & kay_KDAN & T. kaykai & AF082821 & 478 & $\begin{array}{l}\text { Stouthamer et al., } \\
1999\end{array}$ \\
\hline chi_Hawaii & T. chilonis & U74674 & 413 & $\begin{array}{l}\text { Schilthuizen \& } \\
\text { Stouthamer, } 1997\end{array}$ & sat_SAME & T. sathon & AF082815 & 438 & $\begin{array}{l}\text { Stouthamer et al., } \\
1999\end{array}$ \\
\hline cor_Spain & T. cordubensi & U74675 & 416 & $\begin{array}{l}\text { Schilthuizen \& } \\
\text { Stouthamer, } 1997\end{array}$ & sat_SASO & T. sathon & AF082816 & 443 & $\begin{array}{l}\text { Stouthamer et al., } \\
1999\end{array}$ \\
\hline dei_Irvine & T. deion & U74676 & 408 & $\begin{array}{l}\text { Schilthuizen \& } \\
\text { Stouthamer, } 1997\end{array}$ & pra_RDAN & T. pratti & AF082817 & 456 & $\begin{array}{l}\text { Stouthamer et al., } \\
1999\end{array}$ \\
\hline dei_LC & T. deion & U74677 & 406 & $\begin{array}{l}\text { Schilthuizen \& } \\
\text { Stouthamer, } 1997\end{array}$ & pra_RSHE & T. pratti & AF082818 & 451 & $\begin{array}{l}\text { Stouthamer et al., } \\
1999\end{array}$ \\
\hline dei_Menife & T. deion & U74678 & 398 & $\begin{array}{l}\text { Schilthuizen \& } \\
\text { Stouthamer, } 1997\end{array}$ & pre_PMES & T. pretiosum & AF082819 & 406 & $\begin{array}{l}\text { Stouthamer et al., } \\
1999\end{array}$ \\
\hline dei_Pinyon & T. deion & U74679 & 404 & $\begin{array}{l}\text { Schilthuizen \& } \\
\text { Stouthamer, } 1997\end{array}$ & pre_PRV1 & T. pretiosum & AF082820 & 413 & $\begin{array}{l}\text { Stouthamer et al., } \\
1999\end{array}$ \\
\hline dei_Texas & T. deion & U74680 & 405 & $\begin{array}{l}\text { Schilthuizen \& } \\
\text { Stouthamer, } 1997\end{array}$ & alp_ACLE & T. alpha & AF408671 & 393 & Pinto et al., 2002 \\
\hline nub_Nova & T. nubilale & U74600 & 409 & $\begin{array}{l}\text { Schilthuizen \& } \\
\text { Stouthamer, } 1997\end{array}$ & alp_ACOL & T. alpha & AF408672 & 397 & Pinto et al., 2002 \\
\hline ole_Tunesi & T. oleae & U74601 & 399 & $\begin{array}{l}\text { Schilthuizen \& } \\
\text { Stouthamer, } 1997\end{array}$ & alp_ADRK & T. alpha & AF408673 & 395 & Pinto et al., 2002 \\
\hline pla_Newcast & T. platneri & U74603 & 418 & $\begin{array}{l}\text { Schilthuizen \& } \\
\text { Stouthamer, } 1997\end{array}$ & aur_HCLE & T. aurosum & AF408668 & 382 & Pinto et al., 2002 \\
\hline pla_River & T. platneri & U74602 & 418 & $\begin{array}{l}\text { Schilthuizen \& } \\
\text { Stouthamer, } 1997\end{array}$ & aur_HVER & T. aurosum & AF408667 & 385 & Pinto et al., 2002 \\
\hline pre_Hawaii & T. pretiosum & U74604 & 411 & $\begin{array}{l}\text { Schilthuizen \& } \\
\text { Stouthamer, } 1997\end{array}$ & cac_CACA & T. cacoeciae & AF408654 & 465 & Pinto et al., 2002 \\
\hline pre_Mexico & T. pretiosum & U74605 & 414 & $\begin{array}{l}\text { Schilthuizen \& } \\
\text { Stouthamer, } 1997\end{array}$ & cac_CACB & T. cacoeciae & AF408653 & 465 & Pinto et al., 2002 \\
\hline sib_Rich & T. sibericum & U74606 & 443 & $\begin{array}{l}\text { Schilthuizen \& } \\
\text { Stouthamer, } 1997\end{array}$ & cal_CADI & T. californicul & १AF408664 & 439 & Pinto et al., 2002 \\
\hline sib_SIB & T. sibericum & U74607 & 443 & $\begin{array}{l}\text { Schilthuizen \& } \\
\text { Stouthamer, } 1997\end{array}$ & cal_CAYA & T. californicu & AF408663 & 447 & Pinto et al., 2002 \\
\hline bou_Tb26-1 & T. bourarachae & AF04362 & 6556 & Silva et al., 1999 & cal_XALS & T. californicu & $\imath$ AF408661 & 442 & Pinto et al., 2002 \\
\hline bou_Tb26-2 & T. bourarachae & AF04362 & 4553 & Silva et al., 1999 & exi_EXHE & T. exiguum & AF408669 & 380 & Pinto et al., 2002 \\
\hline bou_Tb26-3 & T. bourarachae & AF04362 & 5552 & Silva et al., 1999 & exi_EXSE & T. exiguum & AF408670 & 380 & Pinto et al., 2002 \\
\hline bou_Tb27 & T. bourarachae & AF04362 & 3553 & Silva et al., 1999 & its_ITBO & T. itsybitsi & AF408665 & 381 & Pinto et al., 2002 \\
\hline cor_Tc13 & T. cordubensis & AF04361 & 2416 & Silva et al., 1999 & its_ITBU & T. itsybitsi & AF408666 & 382 & Pinto et al., 2002 \\
\hline cor_Tc14 & T. cordubensis & AF04361 & 9416 & Silva et al., 1999 & min_MBUC6 & T. minutum & AF408659 & 419 & Pinto et al., 2002 \\
\hline cor_Tc15 & T. cordubensis & AF04362 & 0416 & Silva et al., 1999 & min_MCOL & T. minutum & AF408658 & 420 & Pinto et al., 2002 \\
\hline eva_Te5 & T. evanescens & AF04361 & 6429 & Silva et al., 1999 & min_MMIN & T. minutum & AF408660 & 420 & Pinto et al., 2002 \\
\hline eva_Te6 & T. evanescens & AF04361 & 7435 & Silva et al., 1999 & pla_PLIR & T. platneri & AF408655 & 418 & Pinto et al., 2002 \\
\hline eva_Te7 & T. evanescens & AF04361 & 8438 & Silva et al., 1999 & pla_PLME & T. platneri & AF408656 & 418 & Pinto et al., 2002 \\
\hline tur_Tt1 & T. turkestanica & AF04361 & 5372 & Silva et al., 1999 & pla_PLWT & T. platneri & AF408657 & 419 & Pinto et al., 2002 \\
\hline tur_Tt2 & T. turkestanica & AF04361 & 4376 & Silva et al., 1999 & bra_BSSW & T. brassicae & AY163002 & 409 & $\begin{array}{l}\text { Thomson et al., } \\
2003\end{array}$ \\
\hline tur_Tt4 & T. turkestanica & AF04361 & 3376 & Silva et al., 1999 & con_GZ & T. confusum & AY244461 & 394 & unpublished \\
\hline dei_DEUR & T. deion & AF08282 & 3404 & Stouthamer et al., 1999 & & & & & \\
\hline
\end{tabular}

${ }^{a}$ The first 3 letters of Trichogramma species names suffixed with the corresponding strain names represent acronyms for strain designation as described in Table 1 and Table 2.

${ }^{\mathrm{b}} \mathrm{GB}$ ID indicates GenBank accession numbers.

'ITS2 sizes were trimmed from the original sequences as shown in the sequence alignment. 
TABLE 3. Length and GenBank accession numbers of ITS2 sequences identified in this study.

\begin{tabular}{|c|c|c|c|c|}
\hline Strains $^{\mathrm{a}}$ & Species & $\mathrm{GB}_{\mathrm{ID}}^{\mathrm{b}}$ & Length $(b p)^{c}$ & PCR product (bp) ${ }^{\mathrm{c}}$ \\
\hline ost_JL & T. ostriniae & AF250559 & 451 & 641 \\
\hline con_JL & T. confusum & AF422845 & 405 & 595 \\
\hline den_JL & T. dendrolimi & AF227949 & 406 & 596 \\
\hline den_CHA & T. dendrolimi & AF453554 & 407 & 598 \\
\hline den_GZ-clone01 & T. dendrolimi & AF453555 & 407 & 597 \\
\hline den_GZ-clone 02 & T. dendrolimi & AF453556 & 410 & 600 \\
\hline den_GZ- clone 03 & T. dendrolimi & AF453557 & 410 & 600 \\
\hline den_RH & T. dendrolimi & AF453559 & 403 & 594 \\
\hline den_XZ & T. dendrolimi & AF453560 & 403 & 593 \\
\hline den_YBL & T. dendrolimi & AF453561 & 403 & 593 \\
\hline emb_GER & T. embryophagum & AF453562 & 474 & 651 \\
\hline eva_YQ- clone01 & T. evanescens & AF453563 & 431 & 621 \\
\hline eva_YQ- clone02 & T. evanescens & AF453564 & 428 & 618 \\
\hline eva_YQ- clone 03 & T. evanescens & AF453565 & 431 & 622 \\
\hline bra_GER-clone 01 & T. brassicae & AF453566 & 409 & 599 \\
\hline bra_GER-clone 02 & T. brassicae & AF453567 & 406 & 596 \\
\hline mai_FRA-clone 01 & T. maidis & AF453568 & 437 & 625 \\
\hline mai_FRA-clone 02 & T. maidis & AF453569 & 433 & 623 \\
\hline
\end{tabular}

${ }^{a}$ Different clones represent sequences from different individuals of the same line. Strain abbreviations are as described in Table 1.

${ }^{\mathrm{b}} \mathrm{GB}$ ID indicates GenBank accession numbers.

${ }^{\mathrm{c}}$ Length (bp) represents ITS2 without flanking sequences. PCR products (bp) include flanking regions.

between populations of the same species $(0 \sim 7$ bases in complete ITS2 sequences), while ITS2 sequences between species revealed inconsistent divergence. For example, the ITS2 sequences of T. embryophagum and $T$. dendrolimi strain den_RH have a difference of 71 bases, whereas those between $T$. dendrolimi strain den_JL and $T$. brassicae strain bra GER clone02 do not differ in sequence length. Twelve of these ITS2 sequences were aligned with 67 ITS2 sequences taken from GenBank in ClustalW (1.82). DNA Identity Matrix was used, and the data matrices are available at TreeBASE (http://www.treebase.org/treebase/index.html).

\section{Within groups and net between groups average distances}

Within groups or within species, the ITS2 sequences showed little variation (Table 4). No distances could be detected in $T$. platneri using the Complete Deletion option, while a distance of 0.005 was found using the
Pairwise Deletion option. In all cases, within groups average distances were consistently smaller than 0.02 .

Between groups or at the interspecies level, the ITS2 sequences showed much greater divergence than within groups (Table 5). The overall pairwise distance between Trichogramma species is 0.23 ( $\mathrm{n}=27$ groups). The largest pairwise ITS2 distances between Trichogramma species were found between $T$. bourarachae and other Trichogramma species, ranging from 0.634 to 0.826 . There was no divergence between $T$. minutum and $T$. platneri, while the ITS2 distance between T. evanescens and T. maidis was only 0.003 . The ITS 2 sequences indicate that the species in these 2 pairs of Trichogramma species are identical. There are other very closely related Trichogramma species, such as T. alpha / T. aurosum (0.020), T. pretiosum / T. oleae (0.017), T. sathon / $T$. deion $=(0.026)$ and $T$. cacoeciae $/ T$. embryophagum (0.027), all of which have an ITS2 distance of approximately 0.02 , the highest value for within groups average.

TABLE 4. Within groups average distances (Kimura, 1980).

\begin{tabular}{lll}
\hline Groups & Complete deletion (No. of sites $=303 ; \mathrm{d} \pm$ S.E.) & Pairwise deletion (No. of sites $=682 ; \mathrm{d} \pm$ S.E.) \\
\hline T. bourarachae $(\mathrm{n}=4)$ & $0.018 \pm 0.005$ & $0.016 \pm 0.004$ \\
T. deion $(\mathrm{n}=11)$ & $0.013 \pm 0.004$ & $0.013 \pm 0.003$ \\
T. pretiosum $(\mathrm{n}=6)$ & $0.010 \pm 0.004$ & $0.011 \pm 0.003$ \\
T. platneri $(\mathrm{n}=5)$ & $0.000 \pm 0.000$ & $0.005 \pm 0.002$ \\
T. evanescens $(\mathrm{n}=4)$ & $0.004 \pm 0.003$ & $0.008 \pm 0.003$ \\
T. cordubensis $(\mathrm{n}=4)$ & $0.010 \pm 0.004$ & $0.013 \pm 0.004$ \\
T. dendrolimi $(\mathrm{n}=6)$ & $0.005 \pm 0.003$ & $0.008 \pm 0.003$ \\
\hline
\end{tabular}

Standard error (S.E.) estimated by bootstrap method (Replications $=1000)$. 


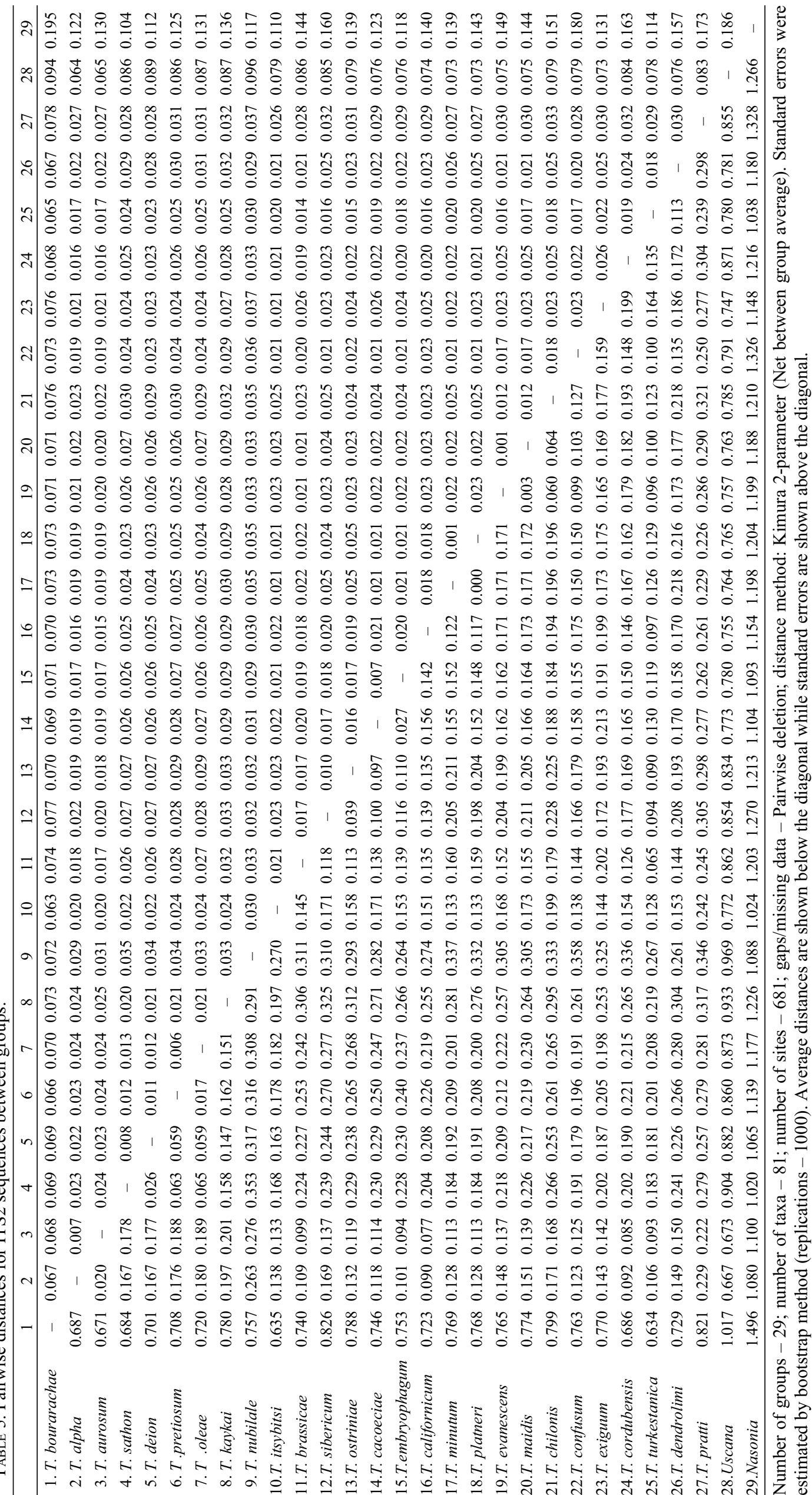




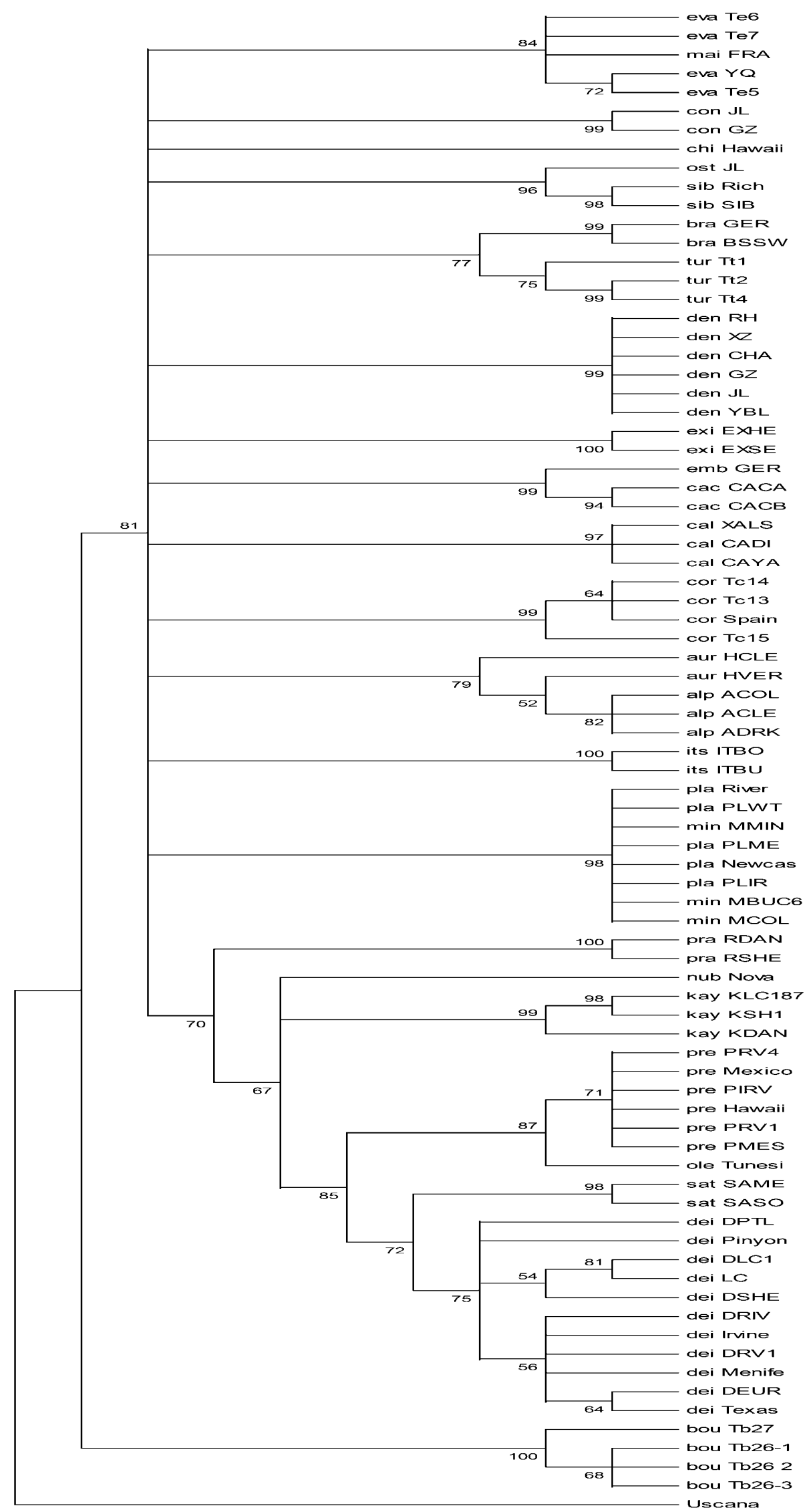

Fig. 1. Rooted NJ tree for 79 Trichogramma species based on Kimura 2-parameter distance model (Kimura, 1980). U. semifumipennis was chosen as outgroup. Bootstrap values for 1000 replicates are shown on the branches. Strain names are as described in Table 1 and Table 2. 
Surprisingly, the distance between $T$. confusum and $T$. chilonis was 0.127 , much greater than expected for within species distances. The overall average distance between U. semifumipennis and Trichogramma species, which could be regarded as an inter-genera ITS2-based distance, was 0.817 , while the inter-family distance between Nasonia vitripennis and Trichogramma species was 1.177 .

\section{Phylogenetic analyses}

Three different tree-making methods were used: Maximum Parsimony (MP), Neighbour-Joining of distances (NJ) and Maximum Likelihood (ML). All three methods gave similar results. A NJ tree was reconstructed for 80 taxa with $U$. semifumipennis as the outgroup (the sum of branch length, SBL $=2.2065$ ). Different distance models were used and all produced similar phylogenetic topologies. The bootstrapped NJ tree is shown in Fig. 1. A search for the most parsimonious trees was performed by branch-and-bound analysis. A total of 58 mostparsimonious trees were found, which required a total of 2683 steps in each site $(\mathrm{CI}=0.784566, \mathrm{RI}=0.581250$, number of informative sites $=309$ ). A bootstrapped search generated the $50 \%$ majority-rule tree in Fig. 2 and yielded 19 nodes with strong support $(>90 \%)$. When evaluated by maximum likelihood (jumble 10×, global rearrangement, randomized input order), the ITS2 datasets produced $24068 \mathrm{ML}$ trees (total weight of positions in analysis $=708$; transition / transversion ratio $=2$; transition / transversion parameter $=1.4765)$. The extended majority rule consensus tree (Fig. 3 ) clearly supported the phylogenetic relationship deduced by using the distance method and parsimony.

In general, all phylogenetic trees generated showed that the ITS2 sequence of T. maidis clustered within $T$. evanescens but not in the same group as T. brassicae, while $T$. confusum and T. chilonis sequences clustered in different branches.

\section{DISCUSSION}

As expected, our studies show that within group or intraspecies divergence is significantly smaller than between groups or interspecies divergence. The ITS2 sequences clearly separated $T$. maidis and $T$. confusum from $T$. brassicae and T. chilonis, respectively. The 6 populations belonging to $T$. dendrolimi formed a distinct and unique clade, and T. maidis is always in the same branch as $T$. evanescens populations in the topologies obtained using different methods. On the basis of the distance data, we concluded that $T$. confusum is not a subspecies of $T$. chilonis, and $T$. maidis is not $T$. brassicae but a cryptic or sibling species of $T$. evanescens. Our results provide the first molecular evidence of the taxonomic status of these previously proposed cryptic species complexes.

The utility of ITS2 as a means of identification was tested on the $T$. deion (Pinto \& Oatman) and T. pretiosum (Riley) complexes (Stouthamer et al., 1999). This indicated it could be used for species identification in Trichogramma, because the sequence variation within species was minor relative to the differences found between species and all the morphologically distinct cryptic species were distinguished by sequence differences. As shown in our topologies, the populations of $T$. deion and $T$. pretiosum clustered as separate groups. Stouthamer et al. (2000) used ITS2 to separate T. minutum (Riley) and $T$. platneri (Nagarkatti), two North American species that cannot be distinguished morphologically (Pinto, 1999), but as no species-specific sequence differences were found the authors suggested that both species had recently diverged from a common ancestor. In all three trees presented in this paper, $T$. minutum and $T$. platneri always cluster together. However, as T. minutum and T. platneri are reproductively incompatible (Nagarkatti, 1975; Pinto et al., 1991), the general correlation between sequence variation and reproductive compatibility is complicated, because the biological species concept is based solely on the fact that they are reproductively compatible. However, as reproductive incompatibility is often associated with differences in morphology and ITS2 sequence structure in many Trichogramma species that have been investigated, the taxonomic status of $T$. minutum and $T$. platneri is questionable. In the case of $T$. maidis and $T$. brassicae, our experiments indicate they are reproductively incompatible (data not shown), and based on this and their ITS2 variation, we conclude they are reproductively isolated species. As for $T$. maidis and $T$. evanescens, they can successfully mate but do not produce offspring. In the future we shall focus on making additional crosses and molecular studies, including studies on mitochondrial DNA (mtDNA). Although the taxonomic position of cryptic species of Trichogramma is still disputable, we suggest that $T$. maidis is a cryptic species of $T$. evanescens, because their ITS2 sequences are nearly identical and in the phylogenetic trees $T$. maidis is embedded in the $T$. evanescens group with a bootstrap support of $84 \%$ in NJ tree or $79 \%$ in MP tree. Insects are notorious for evolving morphologically similar sibling species, so the above needs to be confirmed by additional mating studies and the gathering of other data.

It is important to note that the species status of $T$. confusum is so uncertain that Chinese research workers decided to vote on its relationship with $T$. chilonis at the 1999 National Symposium on Trichogramma (Nai-Quan Lin, pers. commun.), which confirmed that the taxonomic status of $T$. confusum is disputable. Because no crossing experiments have been made, it is difficult to apply the biological species concept. However, the diagnosable differences or genetic distance between $T$. confusum and $T$. chilonis ( 0.127 compared with $<0.02$ within species) and their positions in the trees indicate they are closely related sister species but not cryptic or sibling species.

The potential use of the ITS2 sequence for identifying Trichogramma species depend on sound morphological studies, because traditionally species are morphologically based. In addition to single rearing, the samples (lines) used here were all tested for consistency using hundreds of independent specimens, so the chance of mixing the lines was very unlikely. It should be noted that the 


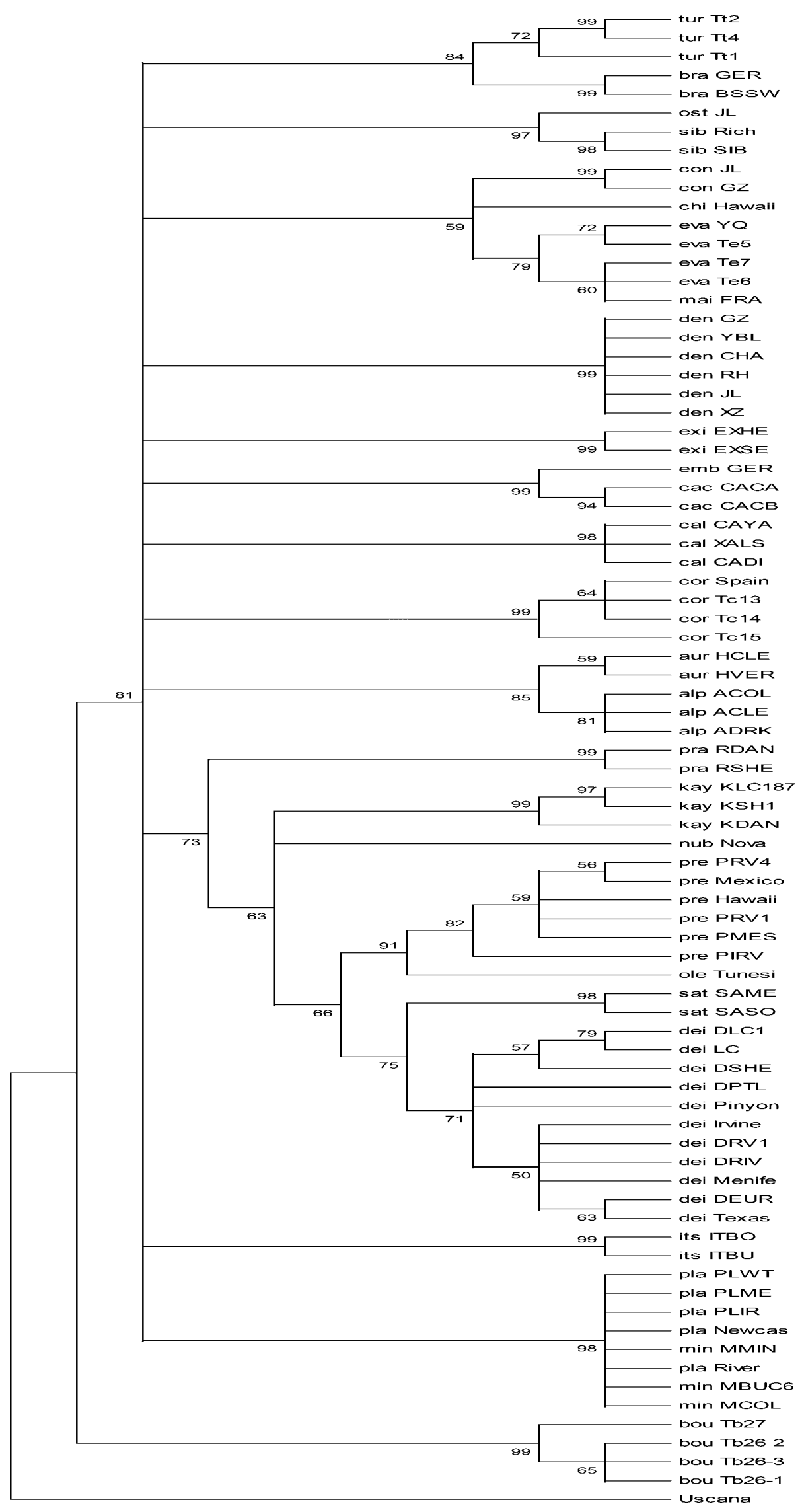

Fig. 2. MP consensus tree for 79 Trichogramma species using U. semifumipennis as outgroup. A total of 58 parsimonious trees were found, which required a total of 2683 steps in each site. Bootstrap values for 1000 replicates are shown on the branches. Strain names are as described in Table 1 and Table 2. 


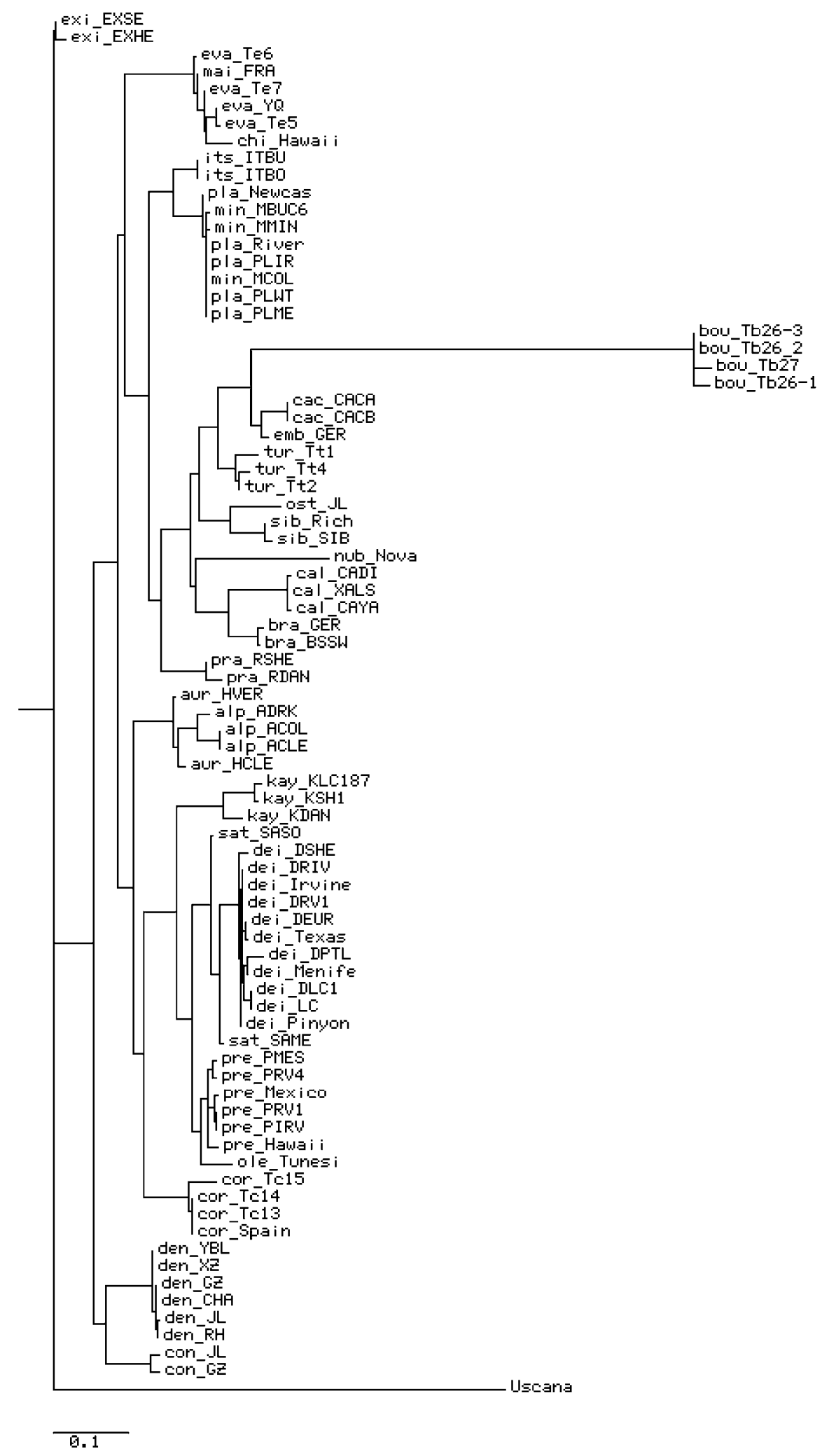

Fig. 3. The extended majority rule consensus ML tree for 79 Trichogramma species using U. semifumipennis as outgroup. A total of $24068 \mathrm{ML}$ trees were examined using fastDNAml version 1.2.2 (Olsen et al., 1994). Total weight of positions in analysis = 708; transition / transversion ratio $=2$; transition / transversion parameter $=1.4765$. Strain names are as described in Table 1 and Table 2 .

sequence data previously reported by different authors and used for phylogenetic analysis in this study all support the formerly discovered conclusions, namely minor within-species and distinct interspecies ITS2 sequence divergence. Moreover, based on comparatively largescale sequence sampling, a baseline that can be regarded as a species border for delineating Trichogramma populations was determined, namely a distance value of approxi- 
mate 0.02 calculated by the Kimura 2-parameter model. Can new taxa be erected on the basis of rDNA differentiation? Is it sufficient to have a distance of about 0.02 to define a new species? Such a baseline does not confirm the existence of a taxonomic relationship. This can only be done by performing crossing experiments as suggested by Pinto et al. (1991).

ACKNOWLEDGEMENTS. We are grateful to S.A. Hassan of the Federal Biological Research Center for Agriculture and Forestry, Institute for Biological Control, Heinrichstr, Darmstadt, Germany, for providing Trichogramma specimens, N.-Q. Lin of the Institute of Pest Biocontrol, Fujian Agricultural University, Fuzhou, China, for the morphological identification of Trichogramma species, J.-W. Wu, S.-Q. Wang, F. Zhang and B. Wang of the Biological Control Center, Academy of Agriculture and Forestry, Beijing, China, for their help with field collection and preliminary identifications of Trichogramma. This work was partially supported by the Open Foundation of the State Key Laboratory for Integrated Management of Agricultural Rodents and Pests affiliated with Institute of Zoology, the Chinese Academy of Sciences (No. 9908).

\section{REFERENCES}

Aeschlimann J.P. 1990: Simultaneous occurrence of thelytoky and bisexuality in hymenopteran species, and its implications for the biological control of pests. Entomophaga 35: 3-5.

Amornsak W., Gordh G. \& Graham G. 1998: Detecting parasitized eggs with polymerase chain reaction and DNA sequence of Trichogramma australicum Girault (Hymenoptera: Trichogrammtidae). Aust. J. Entomol. 37: 174-179.

Campbell B.C., Steffen-Campbell J.D. \& Werren J.H. 1993: Phylogeny of the Nasonia species complex (Hymenoptera: Pteromalidae) inferred from an internal transcribed spacer (ITS2) and 28S rDNA sequences. Insect Mol. Biol. 2: 225-237.

Chang S.C., Hu N.T., Hsin C.Y. \& Sun C.N. 2001: Characterization of differences between two Trichogramma wasps by molecular markers. Biol. Control 21: 75-78.

Doutt R.L. \& Viggiani G. 1968: The classification of the Trichogrammadiae (Hymenoptera: Chalcidoidea). Proc. Calif. Acad. Sci. (Ser. 4) 35: 477-586.

Felsenstein J. 1993: PHYLIP (Phylogeny Inference Package) version 3.5c. Distributed by the author. Department of Genetics, University of Washington, Seattle.

Hassan S.A. \& Zhang W.Q. 2001: Variability in Quality of Trichogramma brassicae (Hymenoptera: Trichogrammatidae) from Commercial Suppliers in Germany. Biol. Control 22: 115-121.

Higgins D., Thompson J., Gibson T., Thompson J.D., Higgins D.G. \& GiBSON T.J. 1994: CLUSTAL W: improving the sensitivity of progressive multiple sequence alignment through sequence weighting, position-specific gap penalties and weight matrix choice. Nucleic Acids Res. 22: 4673-4680.

Hoy M.A. 1994: Insect Molecular Genetics. An Introduction to Principles and Applications. Academic Press, San Diego, 540 pp.

IsHII T. 1941: The species of Trichogramma in Japan, with descriptions of two new species. Kontyu 14: 169-176.

KIMURA M. 1980: A simple method for estimating evolutionary rate of base substitutions through comparative studies of nucleotide sequences. J. Mol. Evol. 16: 111-120.

Kumar S., Tamura K., Jakobsen I.B. \& Nei M. 2001: MEGA2: Molecular Evolutionary Genetics Analysis Software. Arizona State University, Tempe, Arizona, USA.
Landais I., Chavigny P., Castagnone C., Pizzol J., Abad P. \& Vanlerberghe-Masutti F. 2000: Characterization of a highly conserved satellite DNA from the parasitoid wasp Trichogramma brassicae. Gene 255(1): 65-73.

Landry B.S., Dextraze L. \& Boivin G. 1993: Random amplified polymorphic DNA fingerprinting and genetic variability assessment of minute parasitic wasp species (Hymenoptera: Mymaridae and Trichogrammatidae) used in biological control program of phytophagous insects. Genome 36: 580-587.

LIN N.Q. 1994: Systematic studies of Chinese Trichogrammatidae (Hymenoptera: Chalcidoidea). Fujian Science and Technology Publishing House, Fuzhou, Fujian, 362 pp. (in Chinese)

Nagarkatti S. 1975: Two new species of Trichogramma from the USA. Entomophaga 20: 245-248.

Nagarkatti S. \& Nagaraja H. 1971: Redescription of some known species of Trichogramma (Hymenoptera: Trichogrammatidae), showing the importance of the male genitalia as a diagnostic character. Bull. Entomol. Res. 61: 13-21.

Nagarkatti S. \& Nagaraja H. 1977: Biosystematics of Trichogrammatoidea species. Annu. Rev. Entomol. 22: 157-176.

Nagarkatti S. \& Nagaraja H. 1979: The status of Trichogramma chilonis Ishii (Hymenoptera: Trichogrammatidae). Orient. Insects 13: 115-118.

Neto L. \& Pintureau B. 1995: Taxonomic study of a population of Trichogramma turkestanica discovered in Southern Portugal (Hymenoptera: Trichogrammatidae). Ann. Soc. Entomol. Fr. (NS) 31: 21-30.

Olsen G.J., Matsuda H., Hagstrom R. \& Overbeek R. 1994: fastDNAml: A tool for construction of phylogenetic trees of DNA sequences using maximum likelihood. Comput. Appl. Biosci. 10: 41-48.

OrRego C. \& Silva F.A. 1993: Genetic variation in the parasitoid wasp Trichogramma (Hymenoptera: Trichogrammatidae) revealed by DNA amplification of a section of the nuclear ribosomal repeat. Fla Entomol. 76: 519-524.

Pang X.F. 1999: Taxonomic Considerations of Some Cryptic Trichogramma Species. Proceedings of the National Symposium on Trichogramma. Beijing Academy of Agriculture and Forestry Press, Beijing, pp. 4-9 (in Chinese).

PinTo J.D. 1992: Novel taxa of Trichogramma from the New World tropics and Austalia (Hymenoptera: Trichogrammatidae). J. N. Y. Entomol. Soc. 100: 621-633.

Pinto J.D. 1999: Systematics of the North American species of Trichogramma Westwood (Hymenoptera: Trichogrammatidae). Memoirs of the Entomological Society of Washington No. 22 [1998]: 1-287.

Pinto J.D. \& Stouthamer R. 1994: Systematics of the Trichogrammatidae with emphasis on Trichogramma. In Wajnberg E. \& Hassan S.A. (eds): Biological Control with Egg Parasitoids. CAB, Wallingford, Oxon, UK, pp. 1-36.

Pinto J.D., Stouthamer R., Platner G.R. \& Oatman E.R. 1991: Variation in reproductive compatibility in Trichogramma and its taxonomic significance (Hymenoptera: Trichogrammatidae). Ann. Entomol. Soc. Am. 84: 37-46.

Pinto J.D., Kazmer D.J., Platner G.R. \& Sassaman C.A. 1992: Taxonomy of the Trichogramma minutum complex (Hymenoptera: Trichogrammatidae): allozymic variation and its relationship to reproductive and geographic data. Ann. Entomol. Soc. Am. 85: 413-422.

Pinto J.D., Platner G.R. \& Sassaman C.A. 1993: Electrophoretic study of two closely related species of North American Trichogramma, T. pretiosum and T. deion (Hymenoptera: Trichogrammatidae). Ann. Entomol. Soc. Am. 86: 702-709.

Pinto J.D., Stouthamer R. \& Platner G.R. 1997: A new cryptic species of Trichogramma (Hymenoptera: Trichogrammatidae) 
from the Mojave desert of California as determined by morphological, reproductive and molecular data. Proc. Entomol. Soc. Wash. 99: 238-247.

Pinto J.D., Koopmanschap A.B., Platner G.R. \& Stouthamer R. 2002: The North American Trichogramma (Hymenoptera: Trichogrammatidae) parasitizing certain Tortricidae (Lepidoptera) on apple and pear, with ITS2 DNA characterizations and description of a new species. Biol. Control 23: 134-142.

Pintureau B. 1987: Systématique évolutive du Genre Trichogramma Westwood (Hymenoptera: Trichogrammatidae) en Europe. Doctorat Thesis, Université de Paris VII, 311 pp.

Pintureau B. 1993: Enzymatic analysis of the genus Trichogramma (Hymenoptera: Trichogrammatidae) in Europe. Entomophaga 38: 411-431.

Pintureau B. \& Voegole J. 1980: A species near Trichogramma evanescens: T. Maidis, new species. Entomophaga 25: 431-440.

QuednaU W. 1960: Uber die Identitat der Trichogramma Artenund einigerinrer Okotypen (Hymenoptera: Trichogrammatidae). Mitt. Biol. Bundesanst. Lond. Fortwirtch. Berlin, 100: $11-50$.

SAitou N. \& Nei M. 1987: The neighbor-joining method for reconstructing phylogenetic trees. Mol. Biol. Evol. 4(4): 406-425.

Sappal N.P., Jeng R.S., Hubbes M. \& Liu F. 1995: Restriction fragment length polymorphisms in polymerase chain reaction amplified ribosomal DNAs of three Trichogramma (Hymenoptera: Trichogrammatidae) species. Genome 38(3): 419-25.

Schilthuizen M. \& Stouthamer R. 1997: Horizontal transmission of parthenogenesis -inducing microbes in Trichogramma wasps. J. Proc. R. Soc. Lond. (B) 264: 361-366.

Silva I.M.M.S., Honda J., van Kan F.J.P.M., Hu J., Neto L., Pintureau B. \& Stouthamer R. 1999: Molecular differentiation of five Trichogramma species occurring in Portugal. Biol. Control 16: 177-184.

Sмith S.M. \& Hubbes M. 1986: Strains of the egg parasitoid Trichogramma minutum Riley. 1. Biochemical and biological characterization. J. Appl. Entomol. 101: 223-239.

Sorokina A.P. 1993: Keys to the Species of Genus Trichogramma Westw. (Hymenoptera: Trichogrammatidae) of the World Fauna. Kolos, Moscow, 77 pp.
Stouthamer R., Luck R.F., Pinto J.D., Platner G.R. \& StePHENS B. 1996: Non-reciprocal cross-incompatibility in Trichogramma deion. Entomol. Exp. Appl. 80: 481-489.

Stouthamer R., Hu J., Van Kan F., Platner G.R. \& Pinto J.D. 1999: The utility of internally transcribed spacer 2 DNA sequences of the nuclear ribosomal gene for distinguishing sibling species of Trichogramma. BioContol 43: 421-440.

Stouthamer R., Gai Y., Koopmanschap A.B., Platner G.R. \& PINTO J.D. 2000a: ITS-2 sequences do not differ for the closely related species Trichogramma minutum and T. platneri. Entomol. Exp. Appl. 95: 105-111.

Stouthamer R., Jochemsen P., Platner G.R. \& Pinto J.D. 2000b: Crossing incompatibility between Trichogramma minutum and T. platneri and its implications for their application in biological control. Environ. Entomol. 29: 827-837.

Thompson J.D., Gilbson T.J., Plewniak F., Jeanmougin F., HigGINS D.G. 1997: The CLUSTAL_X windows interface: flexible strategies for multiple sequence alignment aided by quality analysis tools. Nucleic Acids Res. 25(24): 4876-4882.

Thomson L.J., Rundle B.J., Carew M., Hoffmann A.A. 2003: Identification and characterization of Trichogramma species from south-eastern Australia using the internal transcribed spacer (ITS-2) region of the ribosomal gene complex. Entomol. Exper. Appl. 106 (3): 235.

van Kan F.J.P.M., Silva I.M.M.S., Schilthuizen M., Pinto J.D. \& StouthameR R. 1996: Use of DNA-based methods for the identification of minute wasps of the genus Trichogramma. Proc. Exper. Appl. Entomol.7: 233-237.

van Kan F. J. P. M., Honda J., Pinto J. D. \& Stouthamer R. 1997: Molecular based techniques for Trichogramma identification. Proc. Exper. Appl. Entomol. 8: 59-62.

Vanlerberghe-Masutti F. 1994: Molecular identification and phylogeny of parasitic wasp species (Hymenoptera: Trichogrammatidae) by mitochondrial DNA RFLP and RAPD markers. Insect Mol. Biol. 3(4): 229-37.

Viggiani G. 1976: Recerche Sugli Hymenoptera Chalcidoidea 49: Trichogramma confusum, n.sp.per T. australicum Nargarkatti et Nagaraja (1968), nec Girault (1912), con not su Trichorammatoidea Girault e descrizione di paratrichogramma heliothidis, n. sp. Insect Mol. Biol. 33: 182-187.

Received June 3, 2003; revised April 2, 2004; accepted May 14, 2004 